\title{
Antiperinuclear factor and keratin antibodies in rheumatoid arthritis
}

G. D. JOHNSON, A. CARVALHO, E. J. HOLBOROW, D. H. GODDARD, AND G. RUSSELL

From the MRC Immunology Group, Bone and Joint Research Unit, The London Hospital Medical College, 25-29 Ashfield Street, London EI 2AD

SUMMARY Tests for antiperinuclear factor (APF) demonstrable by indirect immunofluorescence (IF) on smears of human buccal mucosal cells and for antibodies to keratin (AKA) detected on cryostat sections of rat oesophagus were performed on serum from 102 cases of rheumatoid arthritis (RA) and 117 controls. APF was detected in $92 \%$ of the cases of RA; positive tests obtained with non-RA sera were generally weaker than those given by the RA group, and the antibody in both RA and non-RA serum was predominantly IgG class. The difficulty in obtaining suitable substrate material previously reported was confirmed, and only 2 satisfactory donors were identified among 27 individuals tested. The incidence of keratin antibodies detected was found to be related to the site from which the tissue was taken; low oesophagus provided the best discrimination between RA and controls ( $51 \%$ and $5 \%$ positive respectively), and cardia of the stomach gave the highest incidence of staining in all groups. A laminar staining pattern was seen with most positive sera, but occasionally the keratinised layer was diffusely stained. The presence of AKA showed a marked correlation with both IgM rheumatoid factor and increased Clq binding in RA, but APF did not.

Antibodies to perinuclear cytoplasmic inclusions detectable by indirect immunofluorescence were originally reported by Nienhuis and Mandema in $1964 .{ }^{1}$ The authors suggested that the inclusions, which they found only in human buccal mucosal cells, were keratohyaline granules. A recent report by Sondag-Tschroots et al. $^{2}$ confirmed the association between this antibody and a diagnosis of rheumatoid arthritis.

A further tissue-reactive antibody also detectable by immunofluorescence and associated with rheumatoid arthritis (RA), anti-keratin antibody, was described by Young et al. ${ }^{3}$ This is demonstrated on sections of animal oesophagus, which unlike the human tissue shows a pronounced keratinised layer that is stained with many sera from cases of RA.

We have compared the incidence of these 2 antibodies in sera from patients with rheumatoid arthritis and from other hospital patients and healthy controls in relation to the presence of rheumatoid factor and circulating soluble complexes.

Accepted for publication 7 August 1980

Correspondence to Dr Johnson

\section{Materials and methods}

SERA

The sera were drawn from a bank maintained at $-20^{\circ} \mathrm{C}$ in this Unit. A total of 219 sera were tested; they came from 102 patients with established rheumatoid arthritis (34 males:68 females) attending the Rheumatology Department of the London Hospital, 57 were from control patients shown in Table 1, and 60 from healthy subjects including members of the Unit staff and medical students. As the main aim was to study the correlation between antiperinuclear factor (APF) and antibodies to

\section{Table 1 Control patients}

\begin{tabular}{lc}
\hline Disease & Number of patients \\
\hline Ankylosing spondylitis & 16 \\
Systemic lupus erythematosus & 11 \\
Psoriatic arthritis & 8 \\
Osteoarthrosis & 6 \\
Giant cell arteritis & 4 \\
Juvenile chronic polyarthritis & 2 \\
Dermatomyositis & 2 \\
Bronchitis & 2 \\
Other medical conditions (single cases) & 6 \\
Total & 57 \\
\hline
\end{tabular}


keratin (AKA), no attempt was made to match the groups for age and sex.

\section{ANTIPERINUCLEAR FACTOR}

Preparation of substrate. The inside of the cheek was scraped with a wooden tongue depressor and the cells suspended in $0.01 \mathrm{M}$ phosphate saline, pH 7.4 (PBS). Drops of suspension were air-dried at room temperature on Multispot slides $^{4}$ which were then stored at $-70^{\circ} \mathrm{C}$. In preliminary tests on cells from 27 potential donors only 3 showed characteristic inclusions when stained with a positive serum. One of these showed outstanding staining with a high incidence of positive cells and insignificant bacterial contamination. All the tests reported here were performed on cells obtained from this donor.

Test procedure. The indirect immunofluorescence (IF) method described by Sondag-Tschroots et al. ${ }^{2}$ was followed. Sera were diluted 1:5 and applied to the slides for 90 minutes. FITC-conjugated sheep antihuman immunoglobulin, supplied by Wellcome Reagents Ltd ,was employed in screening tests at its optimal working dilution determined by block titration. ${ }^{5}$ Monospecific conjugates from the same source were used to determine class specificity.

\section{ANTIKERATIN ANTIBODIES}

The immunofluorescence procedure described by Young et al. ${ }^{3}$ (1979) was followed, but rat epithelial tissue from 3 sites was studied-(1) middle third oesophagus, (2) oesophagus immediately proximal to stomach, and (3) cardia of stomach. Sera were tested at a dilution of $1: 10$ and the conjugate was IgG-class specific. In all the IF tests reported here the sera were randomised and read blind.

\section{IMMUNOFLUORESCENCE MICROSCOPY}

A Reichert microscope equipped for transmitted dark-ground illumination was employed. The light source was a $100 \mathrm{~W}$ quartz-halogen lamp, primary filter Balzer FITC-3, secondary filter Ilford $\mathbf{1 1 0 .}$

\section{RHEUMATOID FACTOR DETERMINATION}

Sera were tested for agglutination of latex particles coated with human Ig by a modification of the method described by Singer and Plotz. ${ }^{6}$ A titre of $1: 80$ or higher was regarded as positive. Results were available on 83 cases of RA tested in a routine diagnostic service.

\section{C1 1 BINDING TEST FOR SOLUBLE}

IMMUNE COMPLEXES

The method was based on the procedure described by Zubler and Lambert ${ }^{7}$ in which ${ }^{125} \mathrm{I}-\mathrm{Clq}$ bound to soluble complexes is precipitated by polyethylene glycol. The upper limit of normal is $10 \%$.

\section{Results}

ANTIPERINUCLEAR FACTOR

The incidence is shown in Table 2 . In addition to the sera recorded as positive there were a significant number which gave weak staining, especially in the 2 control groups. The patients who were definitely positive in the control group included 1 case each of systemic lupus erythematosus (SLE), psoriatic arthritis, bronchitis, and 1 with varicose veins.

\section{IMMUNOGLOBULIN CLASS SPECIFICITY}

IgG antibody was predominant, being present in all of 16 rheumatoid and 4 positive normal sera tested with class-specific conjugates. Weaker staining for IgM was obtained with 4 RA sera, and for $\operatorname{IgA}$ with 3 , including 1 normal control.

\section{ANTIKERATIN ANTIBODY}

The incidence is shown in Table 3. There was a marked difference in the results obtained with the various tissues employed. Many of the control sera gave staining of the keratinised layer of the cardia of the stomach, but the staining obtained with oesophagus was confined to serum from RA with only 3 exceptions-2 cases of SLE, 1 of which did not react with middle third oesophagus, and 1 patient suffering from depression. The incidence of positive staining in RA with the 3 tissues showed a gradation from the cardia ( $74 \%$ positive) to the middle third oesophagus ( $41 \%$ positive). The staining pattern obtained with most of the positive sera was distinctly laminar, but occasionally the keratinised layer was diffusely stained. A third, granular, pattern which we have rarely encountered was not seen in the tests reported here.

Table 2 Incidence of antiperinuclear factor (percentages in parentheses)

\begin{tabular}{lrcc}
\hline & Number & $\begin{array}{l}\text { Number } \\
\text { positive }\end{array}$ & $\begin{array}{l}\text { Number } \\
\text { weak positive }\end{array}$ \\
\hline Rheumatoid arthritis & 102 & $82(81)$ & $11(11)$ \\
Control patients & 57 & $4(7)$ & $9(16)$ \\
Normal controls & 60 & $8(14)$ & $12(20)$ \\
\hline
\end{tabular}

Table 3 Incidence of antikeratin antibody (percentages in parentheses)

\begin{tabular}{lrlll}
\hline & Number & Number Positive \\
\cline { 3 - 5 } & & Cardia & $\begin{array}{l}\text { Low } \\
\text { oesophagus }\end{array}$ & $\begin{array}{l}\text { Middle third } \\
\text { oesophagus }\end{array}$ \\
\hline Rheumatoid arthritis & 102 & $75(74)$ & $52(51)$ & $42(41)$ \\
Control patients & 57 & $32(56)$ & $3(5)$ & $3(5)$ \\
Normal controls & 60 & $16(27)$ & $0(0)$ & $0(0)$ \\
\hline
\end{tabular}


Table 4 Correlation between antiperinuclear factor, keratin antibody, and rheumatoid factor in rheumatoid arthritis (percentages in parentheses)

\begin{tabular}{llllll}
\hline Number of patients & Latex test & APF positive & AK.4 positive & APF \& AKA positive APF \& AKA negative \\
\hline 49 & Positive* & $41(84)$ & $30(61)^{* *}$ & $29(59)^{* *}$ & $2(4)$ \\
34 & Negative & $26(76)$ & $11(32)^{* *}$ & $11(32)^{* *}$ & $5(15)$ \\
\hline
\end{tabular}

${ }^{*}$ Titre $\geqslant 1.80 .{ }^{* *} \mathrm{P}<0.02\left(\chi^{2}\right.$ test $)$.

\section{CORRELATION BETWEEN ANTIPERINUCLEAR}

FACTOR AND KERATIN ANTIBODY

Both antibodies were present in 50 patients with RA and absent in only 6 ; 43 patients with RA had antiperinuclear factor only and 1 gave keratin staining only. This was a 65 -year-old female with erosive disease who at the time of the serum sample showed only mild disease activity. She had a latex RF titre $>1: 320$ and gave a Clq binding level of $85 \%$. In the disease control group antiperinuclear factor only was detected in 1 case each of bronchitis, varicose veins, and depression; there were 2 patients with keratin antibody only (SLE and depression), and 1 case of SLE had both antibodies.

\section{CORRELATION BETWEEN ANTIPERINUCLEAR}

FACTOR, KERATIN ANTIBODY, AND

RHEUMATOID FACTOR IN RHEUMATOID

\section{ARTHRITIS}

The correlation between results of the 2 tests and the latex test for rheumatoid factor in RA is shown in Table 4. The best association was with keratin antibody. There were 5 patients who were completely seronegative in the 3 tests. They all gave a history of symmetrical small joint polyarthritis with evidence of erosions on radiography. At the time of the serum sample the disease was inactive in 1 patient and the other 4 showed only moderate activity.

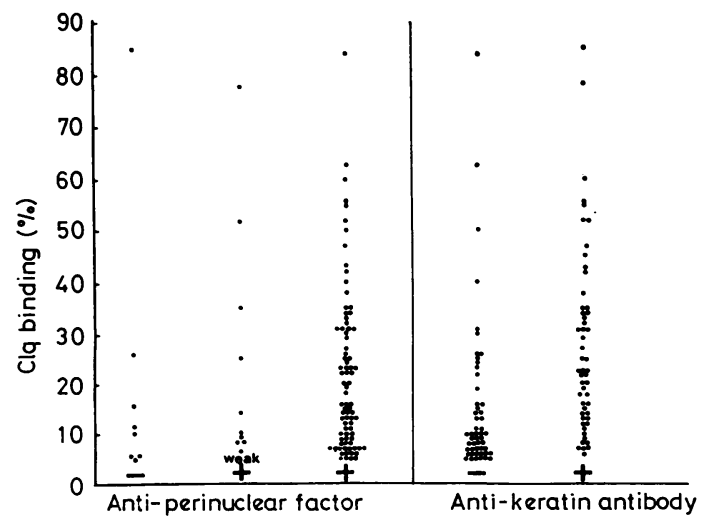

Fig. 1 Distribution of $\mathrm{Clq}$ binding levels in relation to the results of tests for APF and AKA in serum from cases of rheumatoid arthritis.
CORRELATION BETWEEN ANTIPERINUCLEAR FACTOR, KERATIN ANTIBODY, AND THE

LEVEL OF CIRCULATING SOLUBLE

COMPLEXES

The distribution of $\mathrm{Clq}$ binding levels related to the results of the 2 tests is shown in Fig. 1. Increased levels were associated with the presence of keratin antibodies, the incidence of values greater than $10 \%$ being significantly higher in the AKA positive group $\left(P<0.001, \chi^{2}\right.$ test). Levels obtained with serum from the 5 RA patients who were negative for RF, APF, and AKA were normal except in 1 case which gave $26 \%$ binding.

\section{Discussion}

The incidence of antiperinuclear factor we found in RA $(81 \%)$ is very similar to that $(78 \%)$ reported by Sondag-Tschroots et al. ${ }^{2}$ as was our finding in SLE, in which only one case of 11 was positive. However, we found a higher incidence in healthy controls, especially if the weak reactors were included. A further difference between our results and those of the Dutch workers is that we did not find a marked correlation with the presence of rheumatoid factor in RA. The C1q binding levels were also not correlated with the presence of APF. We confirmed the difficulty in obtaining suitable substrate material. Buccal mucosal cells from only 3 of 27 potential normal donors showed stained inclusions when treated with a known APF-positive serum; of these 1 gave outstanding staining of conspicuous inclusions that were present in most of the cells, 1 gave less staining, and results with the third were difficult to interpret because of heavy contamination with bacteria which were stained by the immunofluorescent procedure. Further studies to be reported elsewhere suggest that the reactivity of the 'keratohyaline' granules is the distinguishing feature of cells from suitable donors rather than their presence, which can be demonstrated by other methods in cells that are negative in the IF test.

Antibodies to keratin were detected in $51 \%$ of the RA cases and showed a significant association with the presence of rheumatoid factor, as reported by Young et al. ${ }^{3}$ AKA showed a high degree of specificity for RA, and we also found a correlation 
with levels of $\mathrm{Clq}$ binding. The precise identity of the epithelial antigen involved requires further study and localisation at ultrastructural level. Young (personal communication) has obtained evidence to suggest that the antigen is related to fully differentiated keratin in its native form, and it is evidently distinguishable from the stratum corneum antigen of human skin, which reacts with serum from most normal individuals ${ }^{8}$ - possibly through $\mathrm{Fc}$ binding (W. E. Parish, personal communication). The differences in sensitivity which we found using tissue from different sites, in particular the reduced specificity for RA obtained with sections of cardia of stomach, is unexplained, but this is clearly an important point to take into consideration when applying the test as a screening procedure.

This study has confirmed the association of APF and AKA with rheumatoid arthritis. Their significance in relation to pathogenesis remains to be demonstrated, but they appear to be useful serological markers, the antikeratin antibody having the greater diagnostic potential. The results reported here suggest that the antibodies may be associated with disease activity, but this is based on a limited retrospective analysis. It is proposed to study their incidence further in RA in relation to specific serological and clinical features.
Dr D. H. Goddard was in receipt of a research fellowship from the Arthritis and Rheumatism Council.

\section{References}

1 Nienhuis R L F, Mandema E. A new serum factor in patients with rheumatoid arthritis. The antiperinuclear factor. Ann Rheum Dis 1964; 23: 302-5.

2 Sondag-Tschroots I R J M, Aaij C, Smit J W, Feltkamp $\mathrm{T} E \mathrm{E}$. The antiperinuclear factor. 1: The diagnostic significance of the antiperinuclear factor for rheumatoid arthritis. Ann Rheum Dis 1979; 38: 248-51.

3 Young B J J, Mallya R K, Leslie R D G, Clark C J M, Hamblin $\mathbf{T}$ J. Anti-keratin antibodies in rheumatoid arthritis. Br Med J 1979; ii: 97-9.

4 O'Neill P, Johnson G D. Multispot immunofluorescence: a simple semi-automatic method of processing large numbers of tests. J Clin Pathol 1970; 23: 185-7.

5 Johnson G D, Holborow E J, Dorling J. Immunofluorescence and immunoenzyme techniques. In: Handbook of Experimental Immunology. 3rd ed. Oxford: Blackwell, 1978; ch. 15.

6 Singer J M, Plotz C M. The latex fixation test. 1. Application to the serologic diagnosis of rheumatoid arthritis. Am J Med 1956; 21 : 888-92.

7 Zubler $\mathrm{R} \mathrm{H}$, Lambert $\mathrm{P}$ H. ${ }^{125} \mathrm{I}-\mathrm{Clq}$ binding test for soluble immune complexes. Ann Rheum Dis 1977; 36: (Suppl. 1): 27-30.

8 Kroh H K, Tonder O. Stratum corneum antigens and antibodies. In: Beutner E H, Chorzelski T P, Bean S F, eds. Immunopathology of the Skin. New York: Wiley, 1979: ch. 15. 